\title{
Turn-of-the-month and Intramonth Anomalies and U.S. Macroeconomic News Announcements on the Thinly Traded Finnish Stock Market
}

\author{
Jussi Nikkinen \\ Department of Accounting and Finance, University of Vaasa \\ P.O. Box 700, FIN-65101 Vaasa, Finland \\ Petri Sahlström \\ Department of Accounting and Finance, University of Oulu \\ P.O. Box 4600, FIN-90014 Oulu, Finland \\ Karri Takko \\ Department of Accounting and Finance, University of Vaasa \\ P.O. Box 700, FIN-65101 Vaasa, Finland \\ Janne Äijö (corresponding author) \\ Department of Accounting and Finance, University of Vaasa \\ P.O. Box 700, FIN-65101 Vaasa, Finland \\ Tel: 358-6-324-8276 E-mail: jja@uwasa.fi
}

\begin{abstract}
Evidence from the U.S. stock market as well as from major European stock markets has lately suggested that the turn-of-the-month (hereafter TOM) and intramonth anomalies occur because of major U.S. macroeconomic news announcements that are released around the TOM. World-wide markets are becoming more integrated and therefore in this study we hypothesize that major U.S. macroeconomic news announcements are also the cause for the TOM and intramonth effects on the thinly traded Finnish market. This study uses Finnish data to first identify significant TOM and intramonth effects and second to investigate whether these anomalies arise because of the clustered major U.S. macroeconomic news announcements. Both so-called calendar anomalies are evident, but after controlling for the effect of the major U.S. news releases the anomalies disappear, resulting in further evidence for the significance of the clustered U.S. macroeconomic news announcements. The results of this study are in line with earlier findings and claim that the TOM and intramonth anomalies are driven by the clustered release of major U.S. macroeconomic news announcements.
\end{abstract}

Keywords: Turn-of-the-month, Intramonth, Clustered releases, Macroeconomic news announcements

\section{Introduction}

The turn-of-the-month (TOM hereafter) and intramonth anomalies have aroused the interest of numerous researchers (see e.g. Ariel, 1987; Lakonishok \& Smidt, 1988; Pettengill \& Jordan, 1988; Kunkel, Compton \& Beyer, 2003; McGuinness, 2006). The results of these studies show that stock market returns are significantly higher around the TOM and positive (negative) in the first (second) half of the month (see e.g. Ariel, 1987; Lakonishok \& Smidt, 1988; Cadsby \& Ratner, 1992). These studies report abnormally high returns especially on a few days around the turn-of-the-month (days -1 to +4). For example, Kunkel, Compton and Beyer (2003) examine 19 different stock markets. In 15 countries where the TOM effect is found, it accounts for 87 percent of the monthly returns on average. The research on the TOM and intramonth anomalies has gone on for decades, but has been more broad than profound in nature. Surprisingly, only a few studies have raised the question of the reasons for these anomalies. Potential explanations evinced as the causes for these anomalies includ the periodic flow of funds into the market and the standardization in the payment system (see e.g. Pettengil \& Jordan, 1988; Ogden, 1990). In this study we analyze the recurrence of major U.S macroeconomic news announcements as the reason for the TOM and intramonth anomaly on the Finnish stock market.

While the TOM and intramonth anomalies have been extensively studied, macroeconomic news announcements as the reason for these anomalies have received relatively little attention. It has been documented that some macroeconomic news announcements have greater influence on stock markets than others (see e.g. Bollerslev et al., 2000; Nikkinen \& Sahlström, 2001; Graham, Nikkinen \& Sahlström 2003) such being, for example, the employment report, the producer price index, the employment cost index, retail sales and the ISM (Institute of Supply Management; manufacturing and 
non-manufacturing) survey. (Note 1) The most important announcements are also systematically released at the beginning of the month (Gerlach, 2007; Nikkinen, Sahlström and Äijö, 2007a; 2007b).

Three recent studies deal directly with these issues. Gerlach (2007) and Nikkinen et al. (2007a) study the effects of major U.S. macroeconomic news announcements on the TOM and intramonth anomalies on the U.S. stock market. The results from both papers provide evidence supporting the macroeconomic news announcement hypothesis, i.e. that important U.S. macroeconomic news announcements released in a clustered pattern can be deemed the major reasons for the TOM and intramonth anomalies. The third study, Nikkinen et al. (2007b), study the same issues but on different markets. The study investigates the effect of U.S. macroeconomic news announcements on three major European stock indices. Significant TOM and intramonth effects are found on the DAX, FTSE-100 and CAC indices. Both anomalies disappear after taking the effect of the news announcements into account, meaning that the macroeconomic news announcements are the reason for both anomalies.

The objective of the study is to examine whether the release of clustered U.S. macroeconomic news announcements explain the TOM and intramonth effects on the thinly traded Finnish stock market. This study is motivated by the earlier literature on the integration of financial markets (see e.g. Christie-David, Chaudhry \& Khan, 2002; Nikkinen, Omran, Sahlström \& Äijö, 2006) and by studies on the impacts of U.S. macroeconomic news announcements on European stock markets (see e.g. Nikkinen et al., 2006; Nikkinen et al., 2007b). According to Nikkinen and Sahlström (2004) U.S. macroeconomic news announcements have been found to have a greater effect on European stock markets than comparable domestic announcements. In light of on earlier literature (see e.g. Martikainen, Perttunen \& Puttonen, 1995; Nikkinen et al., 2007b) we hypothesize that TOM and intramonth effects can be found on the Finnish stock market and that the TOM and intramonth anomalies are driven by the release of major U.S. macroeconomic news announcements.

We begin our analysis by investigating whether the TOM effect and related intramonth effect still exist on the Finnish stock market. While Martikainen et al. (1995) document significant TOM effects on the Finnish stock index futures, options, and cash markets, our study moreover investigates whether these anomalies can be explained by the clustered U.S. macroeconomic news announcements. The Finnish stock market is an example of a small, but developed, stock market with relatively low trading volume. The Finnish economy and Finnish firms are heavily dependent on the demand from other countries, which is typical for a smaller European country. For example, in 2005 exports constituted almost $40 \%$ of gross domestic product (GDP). As a comparison, the U.S. export was about $10 \%$ of GDP in 2005 . Furthermore, the proportion of foreign ownership in Finland is quite large as, for example, it was approximately $50 \%$ of the listed stocks in 2006. Therefore, foreign investors have a large role on the Finnish stock market. Because of these characteristics, the Finnish market provides a stark, international contrast to earlier studies done in this field. This study extends the work of Gerlach (2007) and Nikkinen et al. (2007b) by using such a small and specific market as the subject of investigation that the results will contribute additional information to the field of study.

The results of this study are in line with those of earlier studies and further support the macroeconomic news announcement hypothesis. The Finnish market index OMXH25 shows a significant TOM effect on days +1 and +2 with respect to the TOM. An intramonth effect is also found on the Finnish stock market. The results for the intramonth effects are not sensitive to the methodology according to which the month is divided, i.e. the results do not change whether the month is splitt into two halves as in Ariel (1987) or into thirds as in Nikkinen et al. (2007b). After controlling for the effect of macroeconomic news announcements the TOM and intramonth effects are shown to exist no longer, which supports the macroeconomic news announcement hypothesis in a thinly traded stock market.

The structure of the remainder of the study is as follows. The following section describes the hypothesis development and is followed by a section introducing the data used. Section 4 describes the methodology of the study. The empirical results are discussed in Section 5 and the final section concludes and summarizes the findings.

\section{Hypothesis development}

Following Nikkinen et al. (2007a) the hypotheses of this study are based on the following arguments. The reasoning will establish the basis for the macroeconomic news announcements hypothesis. Macroeconomic news announcements are scheduled and well known to investors in advance. They contain pertinent information on the values of financial assets, and therefore affect the valuation of these assets and can be considered as risk factors (see e.g. Ederington et al., 1993; Jones, Lamont \& Lumsdaine, 1998; Fleming \& Remolona, 1999; Christie-David, Chaudhry \& Koch, 2000).

The second argument states that important macroeconomic news announcements are released on certain days of the month and therefore follow a predictable pattern. The majority of these macroeconomic news announcements are clustered in the first half of the month (see e.g. Bollerslev et al., 2000; Graham et al., 2003). Earlier studies also demonstrate that the macroeconomic news announcements issued at the very beginning of the month are of the greatest importance due to their significant information value. 
In creating a reliable base for the hypothesis of the study the last consideration is that trading activities increase around the macroeconomic news announcements when traders bid according to their assessments of the content of the announcements (see e.g. Fleming et al. 1999; Chordia \& Subrahmanyam 2001; Nofsiner \& Prucyk 2003) which increases liquidity. The increase in liquidity is positively related to price changes and, as Karpoff (1987) has shown, this link mainly results from information arrival with a surge in trading volume at the TOM (see e.g. Booth, Kallunki \& Martikainen 2001).

For two main reasons, we hypothesize that U.S. macroeconomic news releases could also be the cause for the TOM and intramonth anomalies on a small European stock market. First, the empirical evidence shows that the European stock markets are affected by the U.S. macroeconomic news releases, and it is the U.S. announcements in particular which have a greater effect on European stock markets than domestic macroeconomic news announcements (see e.g., Nikkinen and Sahlström, 2004; Nikkinen et al., 2006). Second, the European stock markets are highly integrated with the U.S. stock markets. Realized returns and variances are highly correlated on these markets and, most importantly, the U.S. market seems to be the leading source of information (see e.g., Lin et al., 1994; Susmel and Engle, 1994; Bekaert and Harvey 1995; Booth et al., 1997). Thus, it can be hypothesized that the TOM and intramonth anomalies observed on a small European stock market occur due to important U.S. macroeconomic news releases.

\section{Data}

The Finnish market data is taken from the NASDAQ OMX Helsinki 25 index. It is the Helsinki Stock Exchange leading share index and consists of the 25 most traded series on the Helsinki Stock Exchange's Main List. Given the special features of the relatively small Finnish stock market the OMXH25 is a modified-capitalization weighted index where no company's weight is greater than 10 percent. This proves to be important, especially in the case of the world leader in mobile phones, Nokia Corporation. The dataset used in this study covers the period from 1 January 2001 to 28 December 2007. The research data includes exactly 1, 760 trading days on the Finnish market.

The sample of scheduled macroeconomic news releases investigated is largely based on the literature (see e.g. Bollerslev et al., 2000; Graham et al., 2003; Nikkinen et al., 2007b) and on the Bureau of Labor Statistics (BLS) classifications of major economic indicators. Thus, they are selected because of their anticipated importance. This sample consists of the U.S. macroeconomic news releases covering the period between January 2001 and December 2007.

The majority of U.S. announcements are released in the morning at 8:30 a.m. Eastern Time (ET), which corresponds to 3:30 p.m. Finnish time (GMT $+2 \mathrm{~h})$. At the time of the majority of the announcements the U.S. stock market is not open, except for the reports on manufacturing and non-manufacturing of the Institute for Supply Management (ISM), which are released at 10:00 a.m. The Finnish market, however, is open from 10:00 a.m. to 6:30 p.m. local time and has several hours of trading time left when the announcements are released. Since releases are made during the trading hours of the Finnish market, the impact of the releases is incorporated into the closing prices of the Finnish market. The average dates of the announcements, the announcement period and the number of announcements contained in the sample are presented in Table 1. Certain announcements are made consistently on a given day each month, which can be seen in the statistics. For example, the Employment Report is released on the first Friday of the month and the Manufacturing ISM and non-manufacturing ISM reports respectively on the first and third trading days of the month.

(Insert Table 1 about here.)

\section{Methodology}

The daily return $R_{t}$ has been calculated from the following equation:

$$
R_{t}=\ln \left(\frac{O M X H 25_{t}}{O M X H 25_{t-1}}\right)
$$

where $\mathrm{OMXH}_{t}$ is the closing value of the index on day t. To investigate whether the Finnish market exhibits any turn-of-the-month effect we follow the models used in the literature (see e.g. Szakmary \& Kiefer 2004; Nikkinen et al. 2007a; Nikkinen et al. 2007b). Therefore, the following regression model is estimated:

$$
r_{t}=\sum_{i=-9}^{9} \alpha_{i} D_{i, t}+\alpha_{0} R O M_{t}+\varepsilon_{t}
$$

where $r_{t}$ is the stock market return at time $t, i$ refers to the days around the $\operatorname{TOM}(-9,-8, \ldots,+8,+9), D_{i, t}$ stands for the dummy variable taking a value of 1 on day $i$, otherwise zero, ROM is also a dummy variable that takes a value of 1 on the days that fall within the days outside the TOM days (i.e. other than $-9,-8, \ldots,+8,+9$ ), otherwise zero.

To find out whether the Finnish market exhibits an intramonth effect we follow the approach used by Ariel (1987) and divide the month into two halves. Furthermore, we divide the month into three parts compared to Ariel's two. This will 
give us a more detailed view of the phenomenon. The model used by Ariel and the regression derived from Ariel's initial model are as follows:

$$
\begin{gathered}
r_{t}=\alpha_{1} F H_{t}+\alpha_{2} S H_{t}+\varepsilon_{t} \\
r_{t}=\alpha_{1} F T_{t}+\alpha_{2} S T_{t}+\alpha_{3} L T_{t}+\varepsilon_{t}
\end{gathered}
$$

where $F H_{t}$ (first half of the month) takes a value of 1 if day $t$ falls between trading days -1 through +8 relative to the TOM, otherwise zero. $\mathrm{SH}_{t}$ (second half of the month) equals 1 if day $t$ falls within the range of trading days from -10 to -2 relative to the TOM. The first periods of the month (FH and FT) begin at day -1 as in the literature (see e.g. Ariel 1987; Gerlach 2007; Nikkinen et al. 2007a). The variables in Equation (4) are described as follows. $F T_{t}$ (first third of the month) takes a value of 1 if day $t$ constitutes a trading day between -1 and +6 relative to the TOM and otherwise equals zero. $S T_{t}$ (second third of the month) takes a value of 1 if day $t$ falls within the range from +7 to +13 , otherwise zero. Using similar logic $L T_{t}$ (last third of the month) takes a value of 1 if day $t$ falls within the range +14 through +20 , otherwise zero.

In the next phase on the way to determining whether the U.S. macroeconomic news announcements possibly explain the TOM and intramonth effects on the Finnish market we investigate whether the U.S. macroeconomic news announcements affect stock returns on the Finnish market and can therefore be counted as possible causes for the TOM and intramonth effects. The following regression model is constructed to answer this question:

$$
r_{t}=c+\sum_{m=1}^{10} \alpha_{m} M A C R O N E W S_{m, t}+\varepsilon_{t}
$$

where $r_{t}$ is the return for the OMXH25- index on day $t, c$ is the intercept, MACRONEWS ${ }_{m, t}$ is defined as the dummy variable for the macroeconomic news announcements $\left(m=I S M I_{1}, I S M S_{2}, E M P_{3}, \ldots, E C I_{10}\right)$ and takes a value of 1 if the news $m$ occurs and otherwise zero.

Finally, to determine whether or not the U.S. macroeconomic news announcements are the reason for the TOM and intramonth effects on the Finnish market, the residuals ( resid $_{t}$ ) i.e. the error terms estimated from Equation (5) are investigated. These residuals can be thought of as the portion of stock returns that are orthogonal to the risk premiums related to the macroeconomic news announcements, i.e. the effect of U.S. macroeconomic news has been wiped out from the return series. Consequently, if the U.S. macroeconomic news announcements are the reason for the effects, then the effects should not be observed in the residuals estimated from Equation (5). To investigate these issues, the following regression equations are estimated:

$$
\begin{aligned}
& \text { resid }_{t}=\sum_{i=-9}^{9} \alpha_{i} D_{i, t}+\alpha_{0} R O M_{t}+\varepsilon_{t} \\
& \text { resid }_{t}=\alpha_{1} F H_{t}+\alpha_{2} S H_{t}+\varepsilon_{t} \\
& \text { resid }_{t}=\alpha_{1} F T_{t}+\alpha_{2} S T_{t}+\alpha_{3} L T_{t}+\varepsilon_{t}
\end{aligned}
$$


macroeconomic news announcements explain the effects on the Finnish market, then the coefficients for the dummy variables should not differ from zero.

\section{Results}

To find out whether the Finnish stock market does indeed experience a TOM effect we have to examine the regression results from Equation (1). The results are displayed in Table 2 and show significant positive abnormal returns for days +1 and +2 with respect to the TOM. The results are in line with earlier results (see e.g. Lakonishok et al., 1988; Nikkinen et al., 2007b) and they show that the TOM effect is evident for a few days around the TOM. Day -3 is also positively significant but out of the sample TOM days $(-1$ and +3$)$. All regression equations used are corrected for heteroscedasticity with generalized autoregressive conditional heteroscedasticity (GARCH) terms.

(Insert Table 2 about here.)

The intramonth effect on the Finnish market is investigated with Equations (3) and (4), where the month is divided first into two parts and then into three parts. The results in Table 3 show a clear intramonth effect, and therefore, they are in line with the results reported in the literature (see e.g. Ariel, 1987; Lakonishok et al., 1988; Nikkinen et al., 2007b). The returns on the OMXH25 index are significantly higher in the first half and first third of the month. The returns on the 
remaining segments of the month are not significant. These results concur in principle with the findings of Nikkinen et al. (2007b) but do not show an especially strong intramonth effect when the month is divided into three segments.

(Insert Table 3 about here.)

Table 4 presents the results of Equation (5), showing the effect of U.S. macroeconomic news announcements on the Finnish stock market. In contrast to the results presented in the literature we do not find the employment report to have a significant influence on the Finnish market (see e.g. Bollerslev et al., 2000; Nikkinen et al., 2001; Graham et al., 2003; Nikkinen et al., 2006). However, we find that the reports on consumer confidence, gross domestic product, ISM index (previously entitled NAPM manufacturing report) and import and export price indices do have a significant influence on the Finnish market returns.

(Insert Table 4 about here.)

The TOM effect disappears after the macroeconomic news announcement effect has been controlled for and is consistent with previous findings (see e.g. Nikkinen et al. 2007a; Nikkinen et al. 2007b). This investigation is done by estimating Equation (6), where the residuals from Equation (5) were regressed with the day of the month dummies. The coefficient estimate for either day is no longer significant at the $5 \%$ level as can be seen in Table 5 .

(Insert Table 5 about here.)

The results of Equations (7) and (8) are reported in Table 6. The results show whether the U.S. macroeconomic news announcements affect the intramonth anomaly found on the Finnish stock market. If the intramonth effect is explained by the macroeconomic news announcements, the dummy variables from the regression models (7) and (8) should not be statistically significant. The results demonstrate that, once the effect of the U.S. macroeconomic news announcements is taken into account, the intramonth effect disappears in both cases. The results are consistent with similar studies on the effects of U.S. macroeconomic news announcements on the U.S. market as well as on major European markets (see e.g., Gerlach, 2007; Nikkinen et al., 2007a; Nikkinen et al., 2007b).

(Insert Table 6 about here.)

\section{Conclusions}

This study investigates whether TOM and intramonth effects can be found on the thinly traded Finnish stock market and if these anomalies can be explained by the release of major U.S. macroeconomic news announcements that are clustered around the turn-of-the-month. The study is motivated by the special features of the Finnish stock market and its integration into the financial world.

The critical findings of this study were not the discovery of the TOM and intramonth effects but rather the results found to cause these anomalies on the Finnish stock markets, namely clustered U.S. macroeconomic news announcements. Both the TOM and the intramonth effects disappear after the effect the U.S. macroeconomic news announcements on the Finnish market has been controlled for, which in other words means that they create these phenomena. These findings support the hypothesis developed. The results are also in line with the studies on larger markets (see Gerlach 2007; Nikkinen et al. 2007a; Nikkinen et al. 2007b). Out of the ten macroeconomic news announcements investigated the consumer confidence, gross domestic product, the import and export indices and the ISM index were found to have a significant influence on the Finnish market. The results provide further evidence that the global financial markets are integrated and that investors should not turn a blind eye to events that may seem remote. Despite our results that support the hypotheses, it is warranted that the limited sample, i.e. rather short sample period from a single stock market, may affect these results. Thus, our suggestion for future research is as follows. Using a longer data set, it would be interesting to examine whether the TOM and intramonth anomalies on world-wide stock markets (e.g., Asia and emerging stock markets) can be explained by U.S. macroeconomic news announcements.

\section{References}

Ariel, R. (1987). Monthly effects in stock returns. Journal of Financial Economics, 18, 161-174.

Bekaert, G., \& Harvey, C. (1995). Time-varying world market integration. Journal of Finance, 50, 403-444.

Bollerslev, T., Cai J., \& Song, F. (2000). Intraday periodicity, long memory volatility, and macroeconomic announcement Effects in the U.S. Treasury bond market. Journal of Empirical Finance, 7, 37-55.

Booth, G., Chowdhury, M., Martikainen, T., \& Tse, Y. (1997). Intraday volatility international stock index futures markets: meteor showers or heat waves? Management Science, 43, 1564-1576.

Booth, T., Kallunki, J-P., \& Martikainen T. (2001). Liquidity and the turn-of-the-month effect: Evidence from Finland. Journal of International Financial Markets, Institutions and Money, 11, 137-146.

Cadsby, C.B. \& Ratner, M. (1992). Turn-of-the-month and pre-holiday effect on stock return: Some international evidence. Journal of Banking and Finance, 16, 497-509. 
Chordia, T., Roll, R., \& Subrahmanyam, A. (2001). Market liquidity and trading activity. Journal of Finance, 56, 2 501-530.

Christie-David, R., Chaudhry, M., \& Khan, W. (2002). News releases, market integration, and market leadership. Journal of Financial Research, 25:2, 223-245.

Christie-David, R., Chaudhry, M., \& Koch, T. (2000). Do macroeconomic news releases affect gold and silver prices? Journal of Economics and Business, 52, 405-421.

Ederington, L. H., \& Lee, J. H. (1993). How markets process information: News releases and volatility. Journal of Finance, 48:4, 1161-1191.

Fleming, M., \& Remolona, E. (1999). Price formation and liquidity in the U.S. treasury market: The response to public information. Journal of Finance, 54, 1901-1915.

Gerlach, J. (2007). Macroeconomic news and stock market calendar and weather anomalies. Journal of Financial Research, 30:2, 283-300.

Graham, M., Nikkinen, J., \& Sahlström, P. (2003). Relative importance of scheduled macroeconomic news for stock market investors. Journal of Economics and Finance, 27, 153-165.

Jones, C., Lamont, O., \& Lumsdaine, R. (1998). Macroeconomic news and bond market volatility. Journal of Financial Economics, 47, 315-337.

Karpoff, J. (1987). The relation between price changes and trading volume: A survey. Journal of Financial and Quantitative Analysis, 22, 109-126.

Kunkel, R. A., Compton, W. S., \& Beyer, S. (2003). The turn-of-the-month effect still lives: the international evidence. International Review of Financial Analysis, 12:2, 207-222.

Lakonishok, J., \& Smidt, S. (1988). Are seasonal anomalies real? A ninety-year perspective. Review of Financial Studies, 1, 403-425.

Lin, W., Engle, R., \& Ito, T. (1994). Do bulls and bears move across borders? International transmission of stock returns and volatility. Review of Financial Studies, 7, 507-538.

Martikainen, T., Perttunen, J., \& Puttonen, V. (1995). Finnish turn-of-the-month effects: returns, volume and implied volatility. Journal of Futures Markets, 15, 605-615.

McGuinness, P. B. (2006). 'Turn-of-the-month' return effects for small cap Hong Kong stocks. Applied Economics Letters, 13, 891-898.

Nikkinen, J., \& Sahlström, P. (2001). Impact of scheduled U.S. macroeconomic news on stock market uncertainty: A multinational perspective. Multinational Finance Journal, 5:2, 129-148.

Nikkinen, J., \& Sahlström, P. (2004). Scheduled domestic and US macroeconomic news and stock valuation in Europe. Journal of Multinational Financial Management, 14, 201-215.

Nikkinen, J., Omran, M., Sahlström, P., \& Äijö, J. (2006). Global stock market reactions to the scheduled U.S. macroeconomic news announcements. Global Finance Journal, 17:1, 92-104.

Nikkinen, J., Sahlström, P., \& Äijö, J. (2007a). Turn-of-the-month and intramonth effects: Explanation from the important macroeconomic news announcements. Journal of Futures markets, 27, 105-126.

Nikkinen, J., Sahlström, P., \& Äijö, J. (2007b). Do the U.S. macroeconomic news announcements explain turn-of-the-month and intramonth anomalies on European stock markets? Journal of Applied Business and Economics, 7:3.

Nofsinger, J., \& Prucyk, B. (2003). Option volume and volatility response to scheduled economic news releases. Journal of Futures Markets 23, 315-345.

Odgen, J. (1990). Turn-of-the-month evaluations of liquid profits and stock returns: A common explanation for the monthly and January effects. Journal of Finance, 45, 1259-1272.

Patell, J., \& Wolfson, M. (1981). The ex ante and ex post price effects of quarterly earnings announcements reflected in option and stock prices. Journal of Accounting Research, 19:2, 434-458.

Pettengill, G., \& Jordan, B. (1988). A comprehensive examination of volume effects and seasonality of daily security returns. Journal of Financial Research, 11, 57-70.

Susmel, R., \& Engle, R. (1994). Hourly volatility spillovers between international equity markets. Journal of International Money and Finance, 13, 3-25.

Szakmary, A., \& Kiefer, D. (2004). The disappearing january/turn of the year effect: Evidence from stock index futures and cash markets. Journal of Futures Markets, 24, 756-784. 


\section{Notes}

Note 1. On the impact of macroeconomic news announcements of financial markets see e.g. Patell \& Wolfson (1981), Ederington \& Lee (1993), Bollerslev, Cai \& Song (2000), Graham, Nikkinen \& Sahlström (2003).

Table 1. Macroeconomic news announcements.

\begin{tabular}{|c|c|c|c|c|}
\hline Report m: & Symbol & Interval & $\begin{array}{c}\text { \# of } \\
\text { releases }\end{array}$ & $\begin{array}{l}\text { Release } \\
\text { date }^{\mathrm{a}}\end{array}$ \\
\hline $\begin{array}{l}\text { 1. Institute for Supply } \\
\text { Management } \mathrm{t}^{\mathrm{b}} \text { : Manufacturing }\end{array}$ & ISM & Monthly & 84 & 1.0 \\
\hline $\begin{array}{l}\text { 2. Institute for Supply } \\
\text { Management }{ }^{\mathrm{b}} \text { : Non-manufacturing }\end{array}$ & ISMS & Monthly & 84 & 3.0 \\
\hline 3. Employment & EMP & Monthly & 84 & 4.0 \\
\hline 4. Retail Sales & RS & Monthly & 83 & 9.3 \\
\hline 5. Producer Price Index & PPI & Monthly & 84 & 9.9 \\
\hline $\begin{array}{l}\text { 6. Import and Export Price } \\
\text { Indices }\end{array}$ & IEPI & Monthly & 84 & 10.4 \\
\hline 7. Consumer Price Index & CPI & Monthly & 84 & 11.8 \\
\hline 8. Consumer Confidence & CONSCON & Monthly & 82 & 18.8 \\
\hline 9. Gross Domestic Product & GDP & Quarterly & 28 & 19.4 \\
\hline 10. Employment Cost Index & EMPCOST & Quarterly & 28 & 19.7 \\
\hline
\end{tabular}

NOTES: a) Average release day of the month measured by trading days.

b) ISM reports were previously titled National Association of Purchasing Management reports.

Table 2. The existence of the turn-of-the-month effect.

\begin{tabular}{ccrc}
\hline TOM-days & OMXH25 & & \\
& Estimate & t-statistic & p-value \\
-8 & 0.0014 & 1.2751 & 0.2023 \\
-7 & -0.0009 & -0.8748 & 0.3817 \\
-6 & 0.0006 & 0.5717 & 0.5675 \\
-5 & 0.0012 & 1.0429 & 0.2970 \\
-4 & -0.0018 & -1.4733 & 0.1407 \\
-3 & -0.0014 & -1.3278 & 0.1843 \\
-2 & $\mathbf{0 . 0 0 2 7}$ & 2.3091 & 0.0209 \\
-1 & 0.0016 & 1.6787 & 0.0932 \\
1 & 0.0009 & 0.7711 & 0.4406 \\
2 & $\mathbf{0 . 0 0 4 4}$ & 3.5264 & 0.0004 \\
3 & $\mathbf{0 . 0 0 2 4}$ & 2.5067 & 0.0122 \\
4 & 0.0007 & 0.5933 & 0.5530 \\
5 & 0.0018 & 1.8155 & 0.0695 \\
6 & -0.0011 & -1.0971 & 0.2726 \\
4 & -0.0004 & -0.2773 & 0.7816 \\
8 & 0.0022 & 1.8618 & 0.0626 \\
9 & -0.0009 & -0.7741 & 0.4389 \\
ROM & 0.0012 & 1.1740 & 0.2404 \\
C & 0.0005 & 0.8315 & 0.4057 \\
\hline ARCH(1) & 0.0000 & 3.9899 & 0.0001 \\
GARCH(1) & 0.0717 & 6.9972 & 0.0000 \\
& 0.9160 & 87.0775 & 0.0000 \\
\hline
\end{tabular}

The regression formula takes the following form: $\quad r_{t}=\sum_{i=-9}^{9} \alpha_{i} D_{i, t}+\alpha_{0} R O M_{t}+\varepsilon_{t}$

where $r_{t}$ is the stock market return at time $t, i$ refers to the days around the TOM $(-9,-8, \ldots,+8,+9), D_{i, t}$ stands for the dummy variable taking a value of 1 on day $i$, otherwise zero, $R O M_{t}$ is also a dummy variable that takes a value of 1 on the days that fall within the group outside of the TOM days (i.e. other than $-9,-8, \ldots,+8,+9$ ), otherwise zero. In the equation $\alpha_{i}$ and $\alpha_{0}$ are the coefficients and $\varepsilon_{t}$ stands for the disturbance term. The regressions are corrected for heteroscedasticity with GARCH terms. Estimates that are significant at the $5 \%$ level are in bold face. 
Table 3. The existence of the intramonth effect.

\begin{tabular}{crrr}
\hline Segments & $\begin{array}{c}\text { OMXH25 } \\
\text { Estimate }\end{array}$ & p-value \\
\hline FH & $\mathbf{0 . 0 0 1 1}$ & 2.8977 & 0.0038 \\
SH & 0.0005 & 1.4885 & 0.1366 \\
C & & & \\
ARCH(1) & 0.0000 & 4.3963 & 0.0000 \\
GARCH(1) & 0.0651 & 7.3340 & 0.0000 \\
& 0.9232 & 101.5089 & 0.0000 \\
FT & & & 0.0031 \\
ST & $\mathbf{0 . 0 0 1 2}$ & 2.9572 & 0.2163 \\
LT & 0.0005 & 1.2363 & 0.4381 \\
C & 0.0003 & 0.7753 & \\
ARCH(1) & & & 0.0000 \\
GARCH(1) & 0.0000 & 4.4460 & 0.0000 \\
& 0.0650 & 7.3274 & 0.0000 \\
\hline
\end{tabular}

The regression formula takes the following form: $r_{t}=\alpha_{1} \mathrm{FH}_{t}+\alpha_{2} S \mathrm{H}_{t}+\varepsilon_{t}$

$$
r_{t}=\alpha_{1} F T_{t}+\alpha_{2} S T_{t}+\alpha_{3} L T_{t}+\varepsilon_{t}
$$

where $\mathrm{FH}_{t}$ (first half of the month) takes a value of 1 if day $t$ falls between trading days -1 through +8 relative to the TOM, otherwise zero. $S_{t}$ (second half of the month) equals 1 if day $t$ falls within the range of trading days from -10 to -2 relative to the TOM. The first periods of the month (FH and FT) begin at day -1 as in the literature. The variables in Equation (4) are described as follows. $F T_{t}$ (first third of the month) takes a value of 1 if day $t$ constitutes a trading day between -1 and +6 relative to the TOM and otherwise equals zero. $S T_{t}$ (second third of the month) takes a value of 1 if day $t$ falls within the range from +7 to +13 , otherwise zero. Using similar logic $L T_{t}$ (last third of the month) takes a value of 1 if day $t$ falls within the range +14 through +20 , otherwise zero. The regressions are corrected for heteroscedasticity with GARCH terms. Estimates that are significant at the $5 \%$ level are in bold face.

Table 4. Impact of macroeconomic news announcements on stock returns.

\begin{tabular}{ccrc}
\hline & OMXH25 & & \\
Macroeconomic releases & Estimate & t-statistic & p-value \\
\hline CC & $\mathbf{- 0 . 0 0 4 0}$ & -4.1735 & 0.0000 \\
CPI & 0.0001 & 0.0820 & 0.9346 \\
ECI & -0.0008 & -0.3959 & 0.6922 \\
EMP & 0.0007 & 0.5886 & 0.5561 \\
GDP & $\mathbf{0 . 0 0 4 9}$ & 2.2245 & 0.0261 \\
ISMI & $\mathbf{0 . 0 0 3 3}$ & 2.6826 & 0.0073 \\
ISMS & -0.0014 & -1.1333 & 0.2571 \\
PPI & -0.0015 & -1.2936 & 0.1958 \\
RS & 0.0008 & 0.6649 & 0.5061 \\
IMP/EXP & $\mathbf{- 0 . 0 0 2 1}$ & -2.2041 & 0.0275 \\
C & $\mathbf{0 . 0 0 0 9}$ & 3.1370 & 0.0017 \\
\hline C & 0.0000 & 4.3057 & 0.0000 \\
ARCH(1) & 0.0697 & 7.4777 & 0.0000 \\
GARCH(1) & 0.9180 & 95.1458 & 0.0000 \\
\hline
\end{tabular}

The regression formula takes the following form: $\quad r_{t}=c+\sum_{m=1}^{10} \alpha_{m}$ MACRONEWS $_{m, t}+\varepsilon_{t}$

where $r_{t}$ is the return for the OMXH25- index on day $t, c$ is the intercept, MACRONEWS ${ }_{m, t}$ is defined as the dummy variable for the macroeconomic news announcements $\left(m=I S M I_{1}, I S M S_{2}, E M P_{3}, \ldots, E C I_{10}\right)$, that takes a value of 1 , if the news $m$ occurs and otherwise zero. The regressions are corrected for heteroscedasticity with GARCH terms. Estimates that are significant at the $5 \%$ level are in bold face. 
Table 5. Impact of macroeconomic news announcements on the TOM effect.

\begin{tabular}{crrr}
\hline TOM-days & OMXH25 & p-value \\
\hline-9 & Estimate & t-statistic & 0.5698 \\
-8 & 0.0006 & 0.5684 & 0.1108 \\
-7 & -0.0015 & -1.5944 & 0.7535 \\
-6 & -0.0003 & -0.3140 & 0.7999 \\
-5 & 0.0003 & 0.2535 & 0.0697 \\
-4 & -0.0022 & -1.8136 & 0.3645 \\
-3 & -0.0009 & -0.9068 & 0.0579 \\
-2 & 0.0022 & 1.8965 & 0.4933 \\
-1 & 0.0007 & 0.6851 & 0.5252 \\
1 & 0.0007 & 0.6354 & 0.7376 \\
2 & 0.0004 & 0.3350 & 0.1625 \\
3 & 0.0013 & 1.3966 & 0.4786 \\
4 & 0.0008 & 0.7086 & 0.3158 \\
5 & 0.0010 & 1.0032 & 0.0170 \\
6 & $-\mathbf{0 . 0 0 2 3}$ & -2.3874 & 0.3571 \\
7 & -0.0013 & -0.9210 & 0.1298 \\
8 & 0.0017 & 1.5147 & 0.1972 \\
9 & -0.0014 & -1.2895 & 0.4016 \\
ROM & 0.0009 & 0.8388 & 0.8658 \\
\hline C & -0.0001 & -0.1690 & 0.0001 \\
ARCH(1) & 0.0000 & 3.9530 & 0.0000 \\
GAR(1) & 0.0733 & 7.1882 & 0.0000 \\
\hline
\end{tabular}

The regression formula takes the following form: $\operatorname{resid}_{t}=\sum_{i=-9}^{9} \alpha_{i} D_{i, t}+\alpha_{0} R O M_{t}+\varepsilon_{t}$

where resid, refers to the residuals taken from Equation (5) and the other variables are as previously defined. If U.S. macroeconomic news announcements explain the effects on European markets, then the coefficients for the dummy variables should not differ from zero. The regressions are corrected for heteroscedasticity with GARCH terms. Estimates that are significant at the $5 \%$ level are in bold face.

Table 6. Impact of macroeconomic news announcements on the intramonth effect.

\begin{tabular}{ccrr}
\hline Segments & $\begin{array}{c}\text { OMXH25 } \\
\text { Estimate }\end{array}$ & p-value \\
\hline FH & 0.0001 & t-statistic & 0.7901 \\
SH & -0.0001 & 0.2661 & 0.8211 \\
& & -0.2262 & 0.0000 \\
C & 0.0000 & & 0.0000 \\
ARCH(1) & 0.0698 & 7.3723 & 0.0000 \\
GARCH(1) & 0.9180 & 9.5552 & \\
& & & 0.8289 \\
FT & & & 0.9882 \\
ST & 0.0001 & 0.2161 & 0.5582 \\
LT & 0.0000 & 0.0148 & 0.0000 \\
& -0.0002 & -0.5855 & 0.0000 \\
C & & & 0.0000 \\
ARCH(1) & 0.0000 & 4.4282 & 7.5624 \\
GARCH(1) & 0.0695 & 96.6917 & \\
\hline
\end{tabular}

The regression formula takes the following form:

$$
\begin{aligned}
& \text { resid }_{t}=\alpha_{1} F H_{t}+\alpha_{2} S H_{t}+\varepsilon_{t} \\
& \text { resid }_{t}=\alpha_{1} F T_{t}+\alpha_{2} S T_{t}+\alpha_{3} L T_{t}+\varepsilon_{t}
\end{aligned}
$$

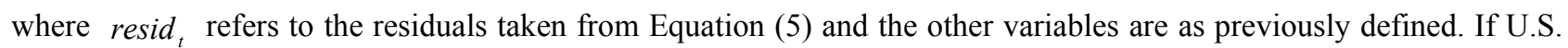
macroeconomic news announcements explain the effects on European markets, then the coefficients for the dummy variables should not differ from zero. The regressions are corrected for heteroscedasticity with GARCH terms. Estimates that are significant at the $5 \%$ level are in bold face. 